\title{
The Bending Strength and Hardness of Recycle Plastic Type HDPE (High Density Polyethylene) and PP (Polypropylene)
}

\author{
Wawan Trisnadi Putra, Kuntang Winangun, Ahmad Yani, Mohamad Afendee Mohamed
}

\begin{abstract}
The purpose of this research is to know the strength, flexibility and maximum hardness of plastic waste after pressing of HDPE, PET/PETE and PP type with bending test. Furthermore, the specimen is made referring to ASTM 6272 D and the testing is carried out with the specified measurement. The results show that the strongest recycled plastic with the highest bending level is obtained from the composition of 50\% HDPE, $20 \%$ PET/PETE and $30 \%$ PP, with maximum power of 52.9 $\mathrm{N} / \mathrm{mm}^{2}$ and $137.74 \mathrm{Kg} / \mathrm{mm}^{2}$. In addition, the biggest flexibility strength is plastic with composition 50\% HDPE, 20\% PET/PETE and $30 \% \mathrm{PP}$ with strength value of $9.53 \mathrm{~N} / \mathrm{mm}^{2}$. As for hardness value, it reaches $12.76 \mathrm{Kg} / \mathrm{mm}^{2}$. Because the plastic in used is recycled Plastic, the resulting product cannot be used for food and beverage container. However, it can be used for flower pot and pencil case.
\end{abstract}

Keywords:Bending test, flexibility, hardness, plastic waste HDPE, PET and PP

\section{INTRODUCTION}

Waste is an integral part of human life. The amount of waste is keeping increasing and the landfill is getting smaller because it has over the limit. A wide range of methods already used to solve this problem but it remains unsolved. With the technology development, the plastic needs are increasing and the plastic waste is also increased. Moreover, the nature of the plastic that cannot decay, not decompose, cannot absorb water and do not rust becomes a serious problem for the environment [1]-[2].

Plastic is a synthetic polymer material that is divided into many types based on it physical, mechanical, and chemical properties [3]. Plastics are generally lightweight; insulator and the production process are cheaper compared to other packaging forms. Based on researches, the type of plastic that widely used by the people is polyethylene. Polyethylene is divided into two parts,highdensitypolyethylene(HDPE) and low-density Polyethylene (LDPE). HDPE is widely used as a

Revised Manuscript Received on December 30, 2019.

* Correspondence Author

WawanTrisnadi Putra, Department of Mechanical Engineering, Universitas Muhammadiyah Ponorogo, Indonesia.

Kuntang Winangun, Department of Mechanical Engineering, Universitas Muhammadiyah Ponorogo, Indonesia.

Ahmad Yani, Department of Mechanical Engineering, Sekolah Tinggi Teknologi Industri Bontang, Indonesia.

MohamadAfendee Mohamed, Faculty of Informatic and Computing, Universiti Sultan Zainal Abidin, Terengganu, Malaysia

(C) The Authors. Published by Blue Eyes Intelligence Engineering and Sciences Publication (BEIESP). This is an open access article under the CC BY-NC-ND license (http://creativecommons.org/licenses/by-nc-nd/4.0/)

beverage bottle,while LDPEused plastic bags [4].

Nowadays, recycle plastic is very popular but only certain plastic can be used as an ornament and the creation of used bottles whereas many alternative recycling that has high selling value and prospective in the future one of which convertsplastic waste into solid objects [5]-[7]. The advantage is it does not absorb water so the content in plastic is very low compared to paper garbage and biomass. In themanufacture process, itrequires materialwith certain specifications and properties to each part, the material must be strong to receive the load above it. The material also must be elastic so it has the standard loading and more durable. In themanufacturing process, the plastic mechanical property has been predicted because we need to know the accurate value of such mechanical properties. Recently, sample material testing has been commonly conducted. This is to know the mechanical properties of the materials so the advantages and the disadvantage can be known.

Bending testing is one of the mechanical properties testing. Testing materials is put in contractions or the materials hold the loading of weight at one central point. Testing for the press loading will give the bending strength and hardness value of the material. One method to know the scale of mechanical Properties of plastic is with bending test. The mechanical properties that can be identified are the flexibility and the hardness of the plastic.

This study is conducted with raw material the plastic waste material that can be used as a reference to make the plastic has high economic value. Thus, this material can be used as raw material for brick and house floor.

\section{LITERATURE REVIEW}

There are many methods which execute in every country to reduce organic and inorganic waste. The waste also develops as crafts that have a high economic value and more promising prospects.

To know the bending power of a material, it should be tested. In flexible testing, the top part of the specimen will experience press energy and the bottom part will experience tensile stress. The bending test uses the following equation [8]:

$$
\sigma b=\frac{3 \mathrm{PL}}{4 b d^{3}}
$$

With:

$$
\begin{aligned}
\sigma b & =\text { bending strength }(\mathrm{N} / \mathrm{mm} 2) . \\
P & =\text { weight }(\mathrm{N}) \\
L & =\text { support distance }(\mathrm{mm}) . \\
d & =\text { specimen thickness }(\mathrm{mm}) . \\
b & =\text { specimen width }
\end{aligned}
$$

(mm). 


\section{The Bending Strength and Hardness of Recycle Plastic Type HDPE (High Density Polyethylene) and PP (Polypropylene)}

In the hardness test, the Vickers hardness designated is used which means the hardness test using Indenter diamond pyramid which has square shape base. The angle between the front on surface of the diamond pyramid is $136^{\circ}$. This value was chosen as it approached most of the preferred comparison values between the curve diameter and the diameter of the pounder ball in the Brinell hardness Test [9]. Hardness figures (Vickers) defined as the weight divided by the surface area of the curve. In practice, this is calculated from the microscopic measurements of long diagonal traces $V H N$ can be determined from the following equations [10]:

$$
V H N=\frac{2 \mathrm{P} \operatorname{Sin}(\varnothing / 2)}{\mathrm{d} 2}=\frac{(1,854) \mathrm{P}}{d 2}
$$

With:

$$
\begin{aligned}
& P=\text { weight used }(\mathrm{N}) \\
& d=\text { average diagonal length }(\mathrm{mm}) \\
& \theta=\text { angle between the facing on diamond surface }=136^{\circ}
\end{aligned}
$$

\section{METHODOLOGY}

The specimen testing uses bending test with ASTM D 6272 standard. The specimen measurement is $127 \mathrm{x} 12.7 \mathrm{x}$ $3.2 \mathrm{~mm}$. The number of specimens for each variation is 5 pieces. The specimen is produced by weighing the plastic mixture about 30-50 gram and melt it using a stove. The stove temperature to melt the plastics is $\pm 300^{\circ} \mathrm{C}$ for $5-10$ minutes. After the plastic melted, the plastic temperature reached \pm $200^{\circ} \mathrm{C}$ then the material poured into a mold until it reached temperature about $\pm 150^{\circ} \mathrm{C}$. Lastly, the specimen is pressed using pressing tool with maximum load $5 \mathrm{~kg}$ and after 1 minute the mold could be opened.

\section{RESULTS AND DICUSSION}

Bending test with ASTM D 6272 standard is a pressure method test/ bending test. Each of plastic mixture consists of several specimens with a composition as presented in Table I. The specimen size is 127 x 12.7 x $3.2 \mathrm{~mm}$ and each variation has five pieces. The produced data is as shown in Table I.

The test specimens are consisted of 4 different compositions.The composition of 50\% HDPE, 20\% PET/PETE and 30\% PP could hold maximum load of $52.9 \mathrm{~N}$ and minimum load of $40.1 \mathrm{~N}$. The average test result shows 52.9 Nwhich is the overall highest test value. The bending test results are presented in Fig. 1.

Table-I: The average test resultswith 5 repetitions

\begin{tabular}{|l|l|l|l|l|}
\hline \multirow{2}{*}{$\begin{array}{l}\text { Number of } \\
\text { Specimen }\end{array}$} & \multicolumn{3}{|c|}{ Plastic Type } & $\begin{array}{l}\text { Maximum } \\
\text { Load(N/mm) }\end{array}$ \\
\cline { 2 - 4 } & HDPE (\%) & PET (\%) & PP (\%) & 28.7 \\
\hline 5 (A1) & 20 & 30 & 50 & 39.6 \\
\hline 5 (A2) & 30 & 50 & 20 & 36.9 \\
\hline 5 (A3) & 40 & 30 & 30 & 52.9 \\
\hline 5 (A4) & 50 & 20 & 30 & \\
\hline
\end{tabular}

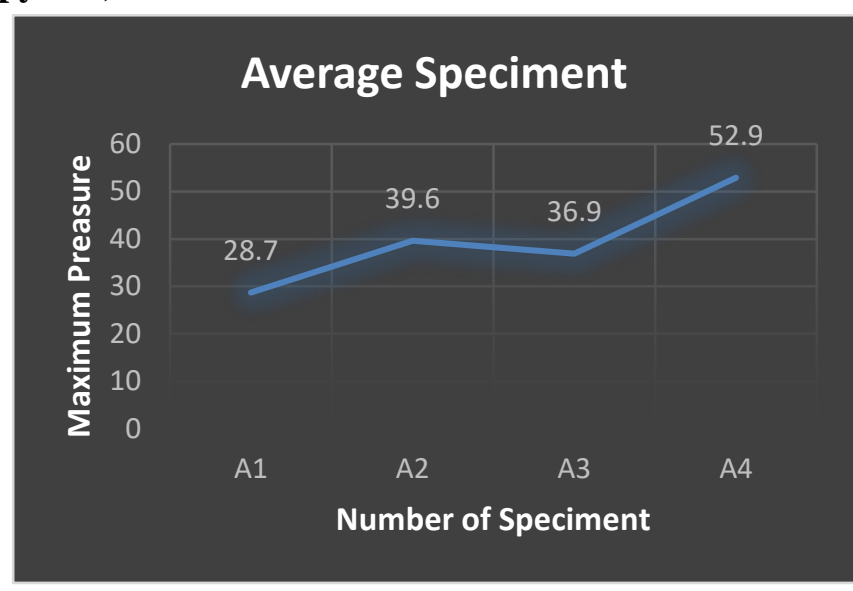

Fig. 1 Bending Test Result

\section{A. The Calculation of Sample Flexible Strength}

HDPE, PET/PETE and PP that could withstand the maximum load are the plastic mixture with composition HDPE 50\%, PET/PETE 20\%, PP 30\%. Thus, the strength of this plastic composition compared with other composition is the most powerful. Whereas the sample mixture with the HDPE 20\%, PET 30\% and PP 50\% composition has the

\begin{tabular}{|c|c|c|c|c|c|c|c|}
\hline \multicolumn{3}{|c|}{ Plastic Type } & \multirow{2}{*}{$\begin{array}{l}\text { Maximum } \\
\text { Weight } \\
(\mathrm{N} / \mathrm{mm})\end{array}$} & \multirow[b]{2}{*}{$\begin{array}{c}\text { I } \\
(\mathrm{mm})\end{array}$} & \multirow[b]{2}{*}{$\begin{array}{c}\mathrm{d} \\
(\mathrm{mm})\end{array}$} & \multirow[b]{2}{*}{$\begin{array}{c}\mathrm{b} \\
(\mathrm{mm})\end{array}$} & \multirow{2}{*}{$\begin{array}{l}\text { Flexible } \\
\text { Strength } \\
\left(\mathrm{N} / \mathrm{mm}^{2}\right)\end{array}$} \\
\hline $\begin{array}{l}\text { HDPE } \\
(\%)\end{array}$ & $\begin{array}{l}\text { PET } \\
(\%)\end{array}$ & $\begin{array}{l}\text { PP } \\
(\%)\end{array}$ & & & & & \\
\hline 20 & 30 & 50 & 28.7 & 100 & 3.2 & 12.7 & 5.17 \\
\hline 30 & 50 & 20 & 39.6 & 100 & 3.2 & 12.7 & 7.13 \\
\hline 40 & 30 & 30 & 36.9 & 100 & 3.2 & 12.7 & 6.65 \\
\hline 50 & 20 & 30 & 52.9 & 100 & 3.2 & 12.7 & 9.53 \\
\hline
\end{tabular}
smallest strength compared to the other compositions. Results of flexible strength can be seen in Table II.

Table-II: Results of flexible strength

Fig. 2 shows the highest maximum load is $9.53 \mathrm{~N} / \mathrm{mm}^{2}$ for a mixture of 50\% HDPE, 20\% PET and 30\% PP. Further more, the lowest maximum load value is $5.17 \mathrm{~N} / \mathrm{mm}^{2}$ for a mixture of 20\% HDPE, 30\% PET and 50\% PP

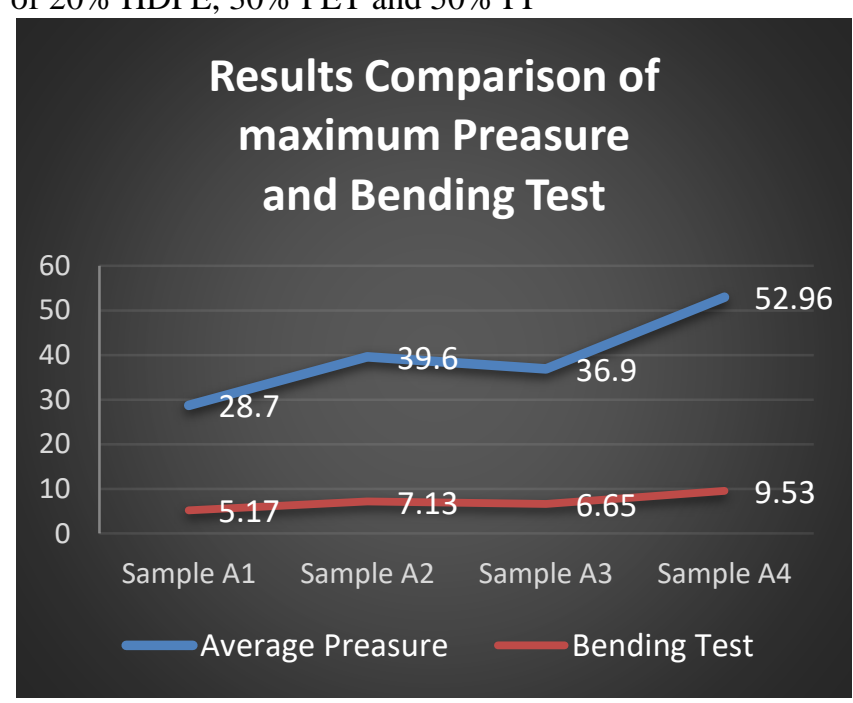

Fig. 2 Results of comparison maximum load and flexible strength

Published By:

Blue Eyes Intelligence Engineering \& Sciences Publication 


\section{B. Hardness Testing}

Thespecimen testis performed to determine the hardness value of the sample with the test result isshown in Table III.

Based on Fig.3,the recycled plastic type HDPE, PET/PETE and PP can withstand the maximum load 137.74 Kg with the composition of HDPE 50\%, PET/PETE 20\%and PP 30\%. Therefore,this type of plastic mixture is the hardestcompared to other mixtures. Whereas the sample with amixture of HDPE 20\%,PET/PETE 30\%and PP 50\% have the lowest strength at $94.84 \mathrm{Kg}$.

Table-III: Hardness Result of the Samples

\begin{tabular}{|c|c|c|c|c|}
\hline \multirow{2}{*}{ No } & \multicolumn{3}{|c|}{ Plastic Type } & \multirow{2}{*}{$\begin{array}{c}\text { Maximum } \\
\text { Load (Kg) }\end{array}$} \\
\cline { 2 - 4 } & HDPE (\%) & PET (\%) & PP (\%) & 94.84 \\
\hline 1 & 20 & 30 & 50 & 106.42 \\
\hline 2 & 30 & 50 & 20 & 121.86 \\
\hline 3 & 40 & 30 & 30 & 137.74 \\
\hline 4 & 50 & 20 & 30 & \\
\hline
\end{tabular}

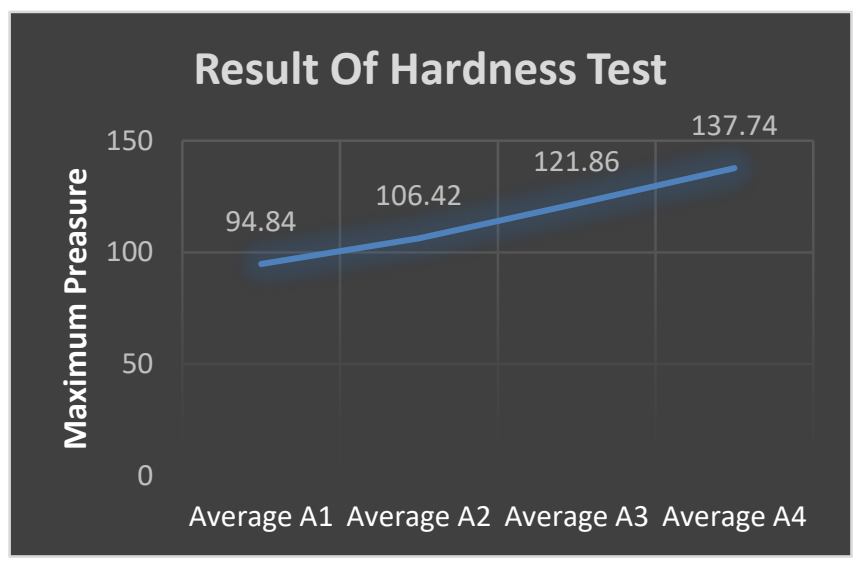

Fig. 3 Hardness Test Result

Fig. 4 shows that the sample number 4 has the most flexible power and hardness. Therefore, this mixture will produce a stronger product compare to other mixtures. Products that can be produced with this recycled plastic for example are flower pot, photo frame, pencil case, and others. However, this type of plastic is not safe to use as a food and drink container because the plastic is recycled plastic from waste or used plastic, so it is not safe to use.

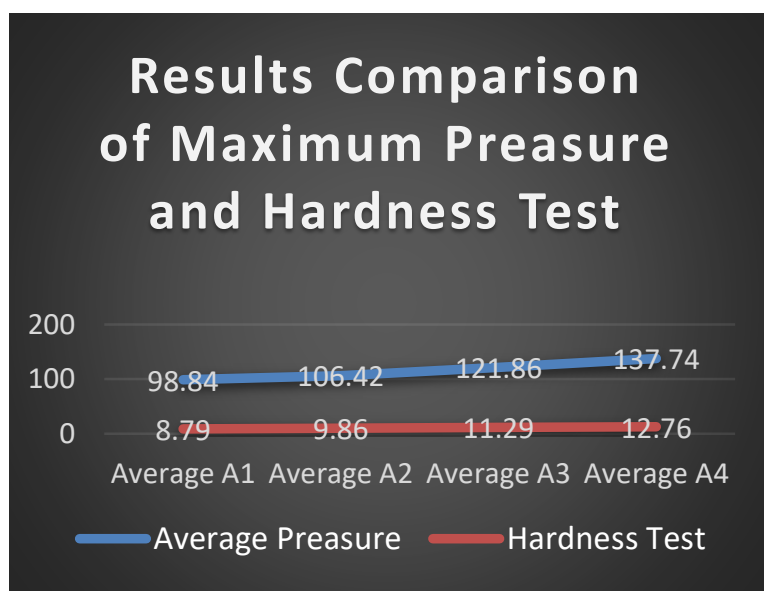

Fig. 4 Comparison of hardness and maximum load

\section{CONCLUSION}

In this paper, the recycled plastic that has the highest level of bending force is obtained from the composition of HDPE 50\%, PET/PETE 20\%, PP 30\% with maximum strength of $52.9 \mathrm{~N} / \mathrm{mm}$ and $137.74 \mathrm{n} / \mathrm{mm}$ for the hardness strength. Whereas the lowest value is obtained from the composition of HDP 20\%, PET/PETE 30\% and PP 50\% with the maximum load of $28.7 \mathrm{~N} / \mathrm{mm}$ and the hardness strength is $94.84 \mathrm{~N}$. The largest flexible strength is from plastic composition of HDPE 50\%, PET/PETE 20\%, PP 30\% with its strength value $9.53 \mathrm{~N} / \mathrm{mm}^{2}$ and the hardness value $12.76 \mathrm{~N} / \mathrm{mm}^{2}$. Of the three plastic mixtures, plastic with a mixture of HDPE 20\%, PET/PETE 30\% and PP 50\% is easily broken; therefore, the HDPE, from the result, has important role to raise the plastic mixture strength.

\section{ACKNOWLEDGMENT}

The authors thank the Government of Malaysia for funding this research under the Fundamental Research Grant Scheme (FRGS/1/2018/ICT03/UNISZA/02/2) and also Universiti Sultan ZainalAbidin, Terengganu, Malaysia.

\section{REFERENCES}

1. P. Singh and V. Sharma. "Integrated plastic waste management: environmental and improved health approaches." Procedia Environmental Sciences, vol. 35, pp. 692-700, 2016.

2. A. Mohammadinia, Y. C. Wong, A.Arulrajah and S. Horpibulsuk. "Strength evaluation of utilizing recycled plastic waste and recycled crushed glass in concrete footpaths." Construction and Building Materials, vol. 197, pp. 489-496, 2019.

3. D. Lithner, A. Larsson and G. Dave. "Environmental and health hazard ranking and assessment of plastic polymers based on chemical composition." Science of the Total Environment, vol. 409, no. 18, pp. 3309-3324, 2011.

4. Q. Zheng, Y. Song, G. Wu andX. Song, "Relationship between the positive temperature coefficient of resistivity and dynamic rheological behavior for carbon black-filled high-density polyethylene." Journal of Polymer Science Part B: Polymer Physics, vol. 41, no. 9, pp. 983-992, 2003.

5. U. N. Ngoc and H. Schnitzer. "Sustainable solutions for solid waste management in Southeast Asian countries." Waste management, vol. 29, no. 6, pp. 1982-1995, 2009.

6. S. M. Kerstens, A.Priyanka, K. C. Van Dijk, F. J. De Ruijter, I.Leusbrock and G. Zeeman. "Potential demand for recoverable resources from Indonesian wastewater and solid waste." Resources, Conservation and Recycling, vol. 110, pp. 16-29, 2016

7. W. T. Putra, S. B.Muhamad, M.Muhamad, M. A. M. Zakaria. "Effectiveness Teston Hardness Performance of Plastic Waste and Sawdust Composite", International Journal of Recent Technology and Engineering, vol. 8, no. 2S7, pp. 273-280, 2019.

8. Siswanto, R. W. E. Sarwono, A. Setyawan and D. H. Setiabudi. "PerubahanSifatLenturKomposit High DesentyPolyethelene (HDP) TerhadapPengaruhFraksi volume pengisiserbukgenteng”. Angkasa, vol. 5, no. 2, pp. 155-158, 2013.

9. O. Richmond, H. L. Morrison and M. L.Devenpeck. "Sphere indentation with application to the Brinell hardness test." International journal of mechanical sciences, vol. 16, no. 1, pp. 75-82, 1974.

10. H. M. Akbar, "AnalisaPengaruhVariasi Preheat Pada Material Api $2 \mathrm{H}$ Gr 50N TO API 2W Gr 50 T TerhadapSifatMekanikdanKetangguhan”. Bachelor Thesis, PoliteknikNegri Surabaya, 2014. 
The Bending Strength and Hardness of Recycle Plastic Type HDPE (High Density Polyethylene) and PP (Polypropylene)

\section{AUTHORS PROFILE}

WawanTrisnadi Putra is currently a Lecturerat the Muhammadiyah University of Ponorogo.He received his M.Sc in Brawijaya University in2012 with specialization in Energy Convertion.The research is in the field of energy convertion,manufacturing technology, material plasticwaste, email: wawantrisnadi@gmail.com

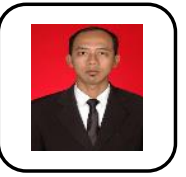

KuntangWinangunis currently a Lecturerat the Muhammadiyah University of Ponorogo, Indonesia since 2017. He received his M.Sc. degree in 2016 from UniversitasNegeri Surabaya of Technology and vocational education, nowhe is a Ph.D candidate in institute teknologisepuluhnopember, Indonesia.Hismain research interestenergy convertion,manufacturing technology, vocational education.

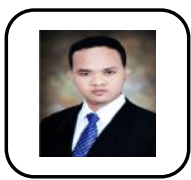

Ahmad Yani, is currently a Lecturer at the SekolahTinggiTeknologiIndustriBontang, Indonesia since 2018. He received his M.Sc in Mechanical Engineering from the UniversitasBrawijaya, Indonesia in 2012. His current research focuses on energy convertion, water turbine analysis, wind turbines, steam engines, solar cells, combustion motors, seawater distillation and biogas.

MohamadAfendeeMohamed,received his PhDin Mathematical Cryptography in 2011 and currentlyserves as an associate professor at UniversitiSultan ZainalAbidin. His research interests includeboth theoretical and application issues in thedomain of data security, and mobile and wireless networking. 